\title{
SEASONAL WEED STRUCTURE OF MAIZE IN THE LIGHT OF FARMING SYSTEMS
}

\author{
ZALAI, M. ${ }^{1}{ }^{*}-$ DORNER, $Z{ }^{1}{ }^{1}-$ KERESZTES, $Z{ }^{1}$ \\ ${ }^{1}$ Szent István University, Faculty of Agricultural and Environmental Sciences, Plant Protection \\ Institute, \\ Hungary, Pater K. str. 1. \\ (phone: +36-28-522-000/ext. 1772; fax: +36-28-522-077) \\ *Corresponding author \\ e-mail:alai.Mihaly@mkk.szie.hu \\ (Received $18^{\text {th }}$ Sept 2013; accepted $04^{\text {th }}$ Dec 2013)
}

\begin{abstract}
The differences between the cultivation of conventional and organic fields can result in changes in weed flora. Although herbicides do not affect all weed species equally, their use can have long-term effects on weeds and may prevent their emergence for weeks after treatment. On the other hand, the common mechanical weed control of organic farms is not selective, but weeds can reappear immediately after the treatment. Nonchemical techniques of weed control are not only used under organic conditions, but also in conventional fields, because of the increasing demands for the restricted use of chemicals in food production. The main aim of our research is to see how different weed control practices result in different weed populations, and how these populations change during the growing season of maize. This work was based on data from 93 conventional and organic maize fields in south-eastern Hungary surveyed between 2007 and 2011. The studied fields were divided into four groups, according to the farming system employed and the season of the survey (conventional in spring, conventional in summer, organic in spring, organic in summer). The aim was to explore the seasonal change of weed flora and the differences between farming systems. Our analysis, which included a comparison of the main weed species, shows that fields managed conventionally and organically are different in terms of both their early and late vegetation. Conventional fields in spring were the most distinct from the other three field groups, as they were not well characterized by any weed species. All the other field groups had dominant species present.
\end{abstract}

Keywords: weed structure, weed flora, organic farming, maize

\section{Introduction}

The organic approach differs from conventional farming in many of its attributes. Systems may be quite diverse in their cultivation structure: for example, the use of pesticides and fertilizers is not permitted in every system. Synthetic chemicals can be used in integrated and conventional systems, yet their use is forbidden in organic farming (EC 834/2007).

In organic farming, cultural, mechanical, physical, and biological methods are all important in weed control, and crop rotation is a generally used technique. The rotation of crops produces a yearly change of ecological conditions, and decreases the seed bank and weed biomass in fields (Brainard et al., 2008). The management of soil outside of the growing period, and the use of cultivars that compete better with weeds, can also serve as elements of prevention (Bond and Grundy, 2011).

The organic approach differs from conventional farming in many ways. An idealistic industrial approach has appeared in intensive agricultural production, whose aim is to become independent from the environment, obtain absolute human control, and to replace natural resources by artificial ones (Ángyán and Lőrinczi, 2003). 
Controlled organic farming has been present in Hungary since 1986, and has become a dynamically developing part of Hungarian agriculture over the last twenty-five years. The total area employing the system increased to over 120,000 hectares by 2004, and the value has been constant since then (Roszik et al., 2012; Kovács, 2012). Organic farming can be regarded as a system of improving vegetable quality (Kolbe et al., 1995, Weibel et al., 2004), and it has become an increasingly popular way of adding extra value to farm products (Dobbs and Smolik, 1996)

In this way, organic farming has become a factor that supports the maintenance of the environment, produces healthy food, carries out agricultural structure reform, uses environment friendly methods of production, and gains social acceptance for agriculture (Bedö, 2006).

The structure of Hungarian farms differs somewhat from the Western European average. While most area is utilized by medium-sized farms in Western Europe, Hungarian acreage is dominated by large farms (Eurostat, 2009). This difference is also visible in organic farming. Although most organic farms are small, organic farming can also be practices on a large scale, though for this to succeed, particular attention needs to be paid to the application of high-level technologies with respect for the environment and knowledge of local conditions. Apart from the many small organic farms, numerous large (many-hundred hectare), long-standing organic farms exist in Hungary, for example the Körös-Maros Biofarm, the Kishantos Ecological Model Farm, and the Galgafarm Co-operative.

Numerous well-known types of organic farming have been developed based on the environmental systems approach. (Bedö, 2006). The use of organic farming has been shown to produce benefit for the environment (Chamberlain et al., 1999; Reganold et al., 2001). When conventional and biodynamic cereals are compared, earthworm casts and weed seedlings are found more frequently in the biodynamic plot. The disaggregation of soil particles in the conventional plots leads to a smoother soil surface (Mäder et al., 2002).

Additionally, one crucial part of the crop protection of organic fields is weed control. Weeds are major factors in yield losses, as they use the water and nutrient reserves of the soil, suppress crop plants, may be reservoirs of crop diseases, and can serve as hiding places for pests. They can increase production costs, cause yield loss, and decrease the value of the product. On the other hand, it is necessary to employ some useful properties of weeds if the unity of the environment is to be maintained. For example, they can decrease wind and water deflation, may be employed as ingredients of pesticides and conditioning agents, and can be used as green manure. Weeds can also help to preserve biodiversity (Radics et al., 2004). Avoiding the use of pesticides and fertilizers has also been shown to lead to changes in weed flora (Pimentel et al., 1997; Gabriel et al., 2006, Szentes et al. 2012).

Additionally, weed flora is affected by the intensity of cultivation. Some segetal species need, to a certain extent, yearly cultivation. The disturbance can create the possibility of beginning a succession, and in this way, annual species can become dominant in the first few years, to be followed by biennial species, and then by perennial. Finally, in some cases, woody species take over the main role of the plant association (Bornkamm, 1985; Tatoni and Roche, 1994). In contrast, Bonet and Pausas (2004) found that annuals were dominant in the first ten years. The structure of pioneer succession is chiefly affected by the crop and by the time of the last cultivation (Hüppe 
and Hofmeister, 1990). These pioneer successions are present in the fields as weed flora.

During the intensive use of landscape, natural ecosystems turn to agroecosystems, and the living spaces became sectioned significantly. This process results in a change in the botanical composition and diversity of the natural habitats, and in the number of species. Inevitably, diversity decreases in the habitats (Edwards et al., 2007).

Additionally, the weed composition does not remain constant during the growing season, with the greatest difference being on account of the annuals. While winter annuals germinate in autumn, or sometimes in early spring, and disappear by summer, summer annuals prefer high temperatures and germinate in spring or summer, finishing seed production by autumn. The frequency of perennials is also higher in summer (Hakansson, 2003).

\section{Material and methods}

\section{Research circumstances}

During our research, the weed species present were identified and classified, and the weed cover and weed structure of both organic and conventional fields were surveyed at different stages.

The aim of our research was to characterize the weed flora of organic and conventional maize fields in the Fehér-Körös River area, and to find differences in weed flora between the different approaches (organic and conventional) used on farms. Surveys were made on an organic farm of more than 2500 hectares (Körös-Maros Biofarm), and at neighbouring conventional farms in the Fehér-Körös River region, near the town of Gyula in southeast Hungary, between 2007 and 2011.

The organic fields were controlled for weeds by harrowing twice (within a week after seeding, and between the 1 and 3 leaf stages of maize) and by use of an inter-row cultivator once or twice. The fields with most weeds were also hoed for weed control. Conventional fields were treated by pre-emergent or early post-emergent herbicides and by inter-row cultivator, and were treated between the 6 and 9 maize leaf stages.

All of the organic fields studied were managed conventionally with intensive use of herbicide prior to the early 1990 s.

A total of 93 fields were surveyed in the study. These fields were divided into four groups, according to the farming system used and the season of the survey (conventional in spring, conventional in summer, organic in spring, and organic in summer). The spring surveys were carried out at the end of April and in May, while the summer surveys were performed between the middle of June and August.

We attempted to answer the following questions during our work on the fields of both farming systems: (a) Which weed species are most typical of conventional and organic maize in the region, and what is the extent of their cover? (b) Does the weed flora of the previously conventionally managed organic fields differ from that of the neighbouring continuously conventional fields? (c) Can weed control without herbicides keep weeds to an acceptable level in maize? (d) Which weed species are the most dangerous and problematic in organic farming? (e) Are there any differences between the organic and conventional systems in terms of weed structure? (f) How do the weedspecies structures of spring (April-May) and summer (June-July) vegetation on organic and conventional fields differ? 
The rate of cover of individual weed species was recorded by direct covering percentage (Németh and Sárfalvi, 1998). The weed cover of each field was estimated based on the mean values of four replicates. Species found only outside the sampling areas were registered as contributing 0.1 percent cover value (Zalai et al., 2012). Weed species were classified as winter annuals, summer annuals, biennials, creeping perennials, or stationary perennials according to Hakansson (2003).

\section{Statistical analysis based on the structure of weed species}

Prior to the analysis, the cover of each weed species was normalized by dividing it by the total weed cover of each field, to show the relative incidence of weed species per field. For preanalysis, one-way MANOVA (Wilks' lambda test) was used to test the difference between groups (Krzanowski, 1988). The main analysis was carried out using linear discriminant analysis (LDA), with the relative incidences of weed species as structure coefficients for the four field groups (conventional in spring, conventional in summer, organic in spring, and organic in summer) (Ripley, 1996; Venables and Ripley 2002). Weeds with lower total cover than $0.5 \%$ of the 93 studied fields were excluded from the analysis. In the figures, for clarity, only the 15 weed species with the highest effects on the model are represented. Linear discriminant number 1 (LD1) with LD2, as well as LD1 with LD3, was also used, on account of the relatively high trace of LD3. All statistical analyses were carried using R (R Development Core Team, 2011).

\section{Results}

\section{Weed flora of conventional maize in spring}

The weed flora of conventional maize fields mainly included creeping perennial and summer annual species in the spring surveys (Table 1).

Convolvulus arvensis and Cirsium arvense were the most frequent perennial species. This is unsurprising, as these species are problematic in most spring-seeded crops in Hungary. They are also important in the Fifth National Weed Survey (Novák et al., 2009), although they were not the most common weed in the Survey.

Table 1. Most frequent weeds of conventional maize in spring

\begin{tabular}{|c|c|c|}
\hline OD* & Weed species* & Cover $[\%]$ \\
\hline & Convolvulus arvensis & 0.38 \\
\hline & Cirsium arvense & 0.31 \\
\hline & Stellaria media & 0.14 \\
\hline & Echinochloa crus-galli & 0.10 \\
\hline & Capsella bursa-pastoris & 0.09 \\
\hline $6-7$ & Fallopia convolvulus & 0.04 \\
\hline $6-7$ & Persicaria lapathifolia & 0.04 \\
\hline $8-10$ & Helianthus annuus & 0.03 \\
\hline $8-10$ & Setaria pumila & 0.03 \\
\hline $8-10$ & Setaria viridis & 0.03 \\
\hline & other & 0.30 \\
\hline & TOTAL & 1.49 \\
\hline
\end{tabular}


Summer annuals were also significant, and these species accounted for approximately half of the total coverage. Both monocotyledonous (such as Echinochloa crus-galli and Setaria spp.) and dicotyledonous species were frequent.

The coverage of winter annuals was low, but Stellaria media and Capsella bursapastoris took the third and fifth places, respectively, in the order of dominance.

The total weed cover was low.

\section{Weed flora of conventional maize in summer}

By summer, the creeping perennial species (Convolvulus arvensis, Cirsium arvense) managed to only slightly increase their coverage in conventional maize (Table 2).

The increase in the coverage of summer annuals was more intense. The order of dominance of these species changed, but Echinochloa crus-galli remained most frequent. Apart from this, other grassy weeds (such as Setaria pumila) and broad-leaved weeds (like Hibiscus trionum) were significant.

A stationary perennial plant (Cichorium intybus) was also present among the top weeds, but the frequency of this group was low.

The total weed coverage increased until late summer, but remained on a tolerable level.

Table 2. Most frequent weeds of conventional maize in summer

$\begin{array}{cc}\text { OD* Weed species }^{*} \text { Cover[\%] } \\ \text { 1. Echinochloa crus-galli } & 1.13 \\ \text { 2. Hibiscus trionum } & 0.68 \\ \text { 3. Convolvulus arvensis } & 0.44 \\ \text { 4. Cirsium arvense } & 0.34 \\ \text { 5. Persicaria lapathifolia } & 0.22 \\ \text { 6. Chenopodium hybridum } & 0.18 \\ \text { 7. Setaria pumila } & 0.11 \\ \text { 8. Abutilon theophrasti } & 0.08 \\ \text { 9. Cichorium intybus } & 0.06 \\ \text { 10. Digitaria sanguinalis } & 0.04 \\ \text { other } & 0.20 \\ \text { TOTAL } & 3.48 \\ \text { *OD order of dominance } & \end{array}$

\section{Weed flora of organic maize in spring}

In the spring survey, Cirsium arvense was the most frequent weed in organic fields. This species was also important for conventional areas, but its coverage was many times greater in organic farming. Conversely, the coverage of Convolvulus arvensis (also a creeping perennial) differed only slightly from its value on conventional fields (Table $3)$.

The summer annual weeds were also significant. Echinochloa crus-galli was the first of these, with more than $1 \%$. Beside this, only one monocotyledon was frequent (Setaria pumila). The number of dicotyledonous annuals was high, and all of the other top species came from this group (including Xanthium strumarium and Abutilon theophrasti). 
The total weed coverage was less than $10 \%$. This is still a tolerable value, but is much higher than for conventional maize.

Table 3. Most frequent weeds of organic maize in spring

$\begin{array}{rc}\text { OD* Weed species } & \text { Cover[\%] } \\ \text { 1. Cirsium arvense } & 1.30 \\ \text { 2. Echinochloa crus-galli } & 1.09 \\ \text { 3. Xanthium strumarium } & 0.47 \\ \text { 4. Abutilon theophrasti } & 0.42 \\ \text { 5. Persicaria lapathifolia } & 0.41 \\ \text { 6. Convolvulus arvensis } & 0.40 \\ \text { 7. Chenopodium album } & 0.29 \\ \text { 8. Amaranthus retroflexus } & 0.28 \\ \text { 9. Setaria pumila } & 0.23 \\ \text { 10. Ambrosia artemisiifolia } & 0.18 \\ \text { other } & 1.79 \\ \text { TOTAL } & 6.86 \\ \text { *OD order of dominance } & \end{array}$

\section{Weed flora of organic maize in summer}

By summer, monocotyledonous annuals had taken the lead in terms of their coverage of organic fields. Echinochloa crus-galli had the highest coverage, as with conventional fields, while Setaria pumila was also important (Table 4).

From the dicotyledonous annual group, Hibiscus trionum showed the greatest coverage. This is the same as on conventional farm, which shows that, just like grassy weeds, Hibiscus trionum is an important species in the studied region. Its high incidence is significant only in late summer.

However, the coverage of perennials (Cirsium arvense and Convolvulus arvensis) multiplied by early summer, and although their incidence was significantly higher than on conventional farms, it was not so high as to allow them to play the main role for organic maize in summer.

Table 4. Most frequent weeds of organic fields in summer

$\begin{array}{rlc}\text { OD* }^{*} \text { Weed species } & \text { Cover[\%] } \\ 1 \text { Echinochloa crus-galli } & 6.92 \\ 2 & \text { Setaria pumila } & 3.52 \\ 3 & \text { Cirsium arvense } & 3.08 \\ 4 & \text { Hibiscus trionum } & 2.72 \\ 5 & \text { Convolvulus arvensis } & 1.78 \\ 6 \text { Amaranthus retroflexus } & 1.29 \\ 7 \text { Chenopodium album } & 1.28 \\ 8 \text { Abutilon theophrasti } & 0.68 \\ 9 & \text { Ambrosia artemisiifolia } & 0.51 \\ 10 \text { Datura stramonium } & 0.33 \\ & \text { other } \\ \quad \text { TOTAL } & 2.52 \\ \text { *OD order of dominance } & 24.63\end{array}$


The total weed coverage was close to one quarter of the total area. This is higher than the damage limit value, in spite of the employment of continuous weed management.

\section{Weed structure of organic and conventional maize fields}

According to linear discriminant analysis with LD1 with LD2 $(79.08 \%$ of the total trace), conventional fields in spring differ significantly from the other field groups (Fig. 1). Conventional and organic fields differ more in spring, and this difference was no longer significant by summer. The change in the structure of the weed flora was greater in conventional fields than in organic fields from spring until summer.

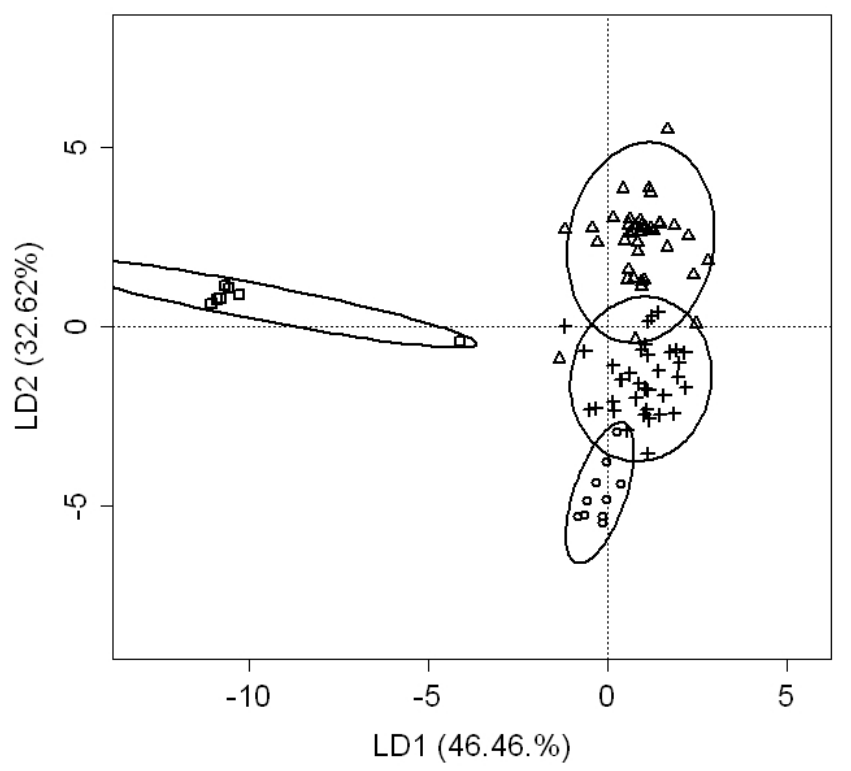

Figure 1. Discrimination of organic and conventional fields in spring and in summer by weed structure according to LD1 and LD2 ( $\square$ conventional in spring, $\circ$ conventional in summer,

$\triangle$ organic in spring, + organic in summer)

Using LD1 with LD3 shows the same difference between conventional fields in spring and the other field groups (Fig. 2). The position of the organic fields interchanged from spring to summer, meaning that conventional and organic fields also differed significantly in summer. The weed structure of the organic fields in spring did not differ significantly from that of conventional fields in summer. Organic fields in different seasons did not vary, regardless of whether LD1 with LD2 or LD1 with LD3 was used.

On the basis of LD1 with LD2, most impact species can be classified into four groups. Weed group 1 includes the winter annual species (such as Capsella bursapastoris and Lamium spp.) that were present mainly on organic fields in spring. These are wintering or early spring germinating annual plants, and are less typical in maize than they are in cereals. Their cover was also low on organic fields in spring, but almost no winter annuals were present in the other field groups (Fig. 3). 


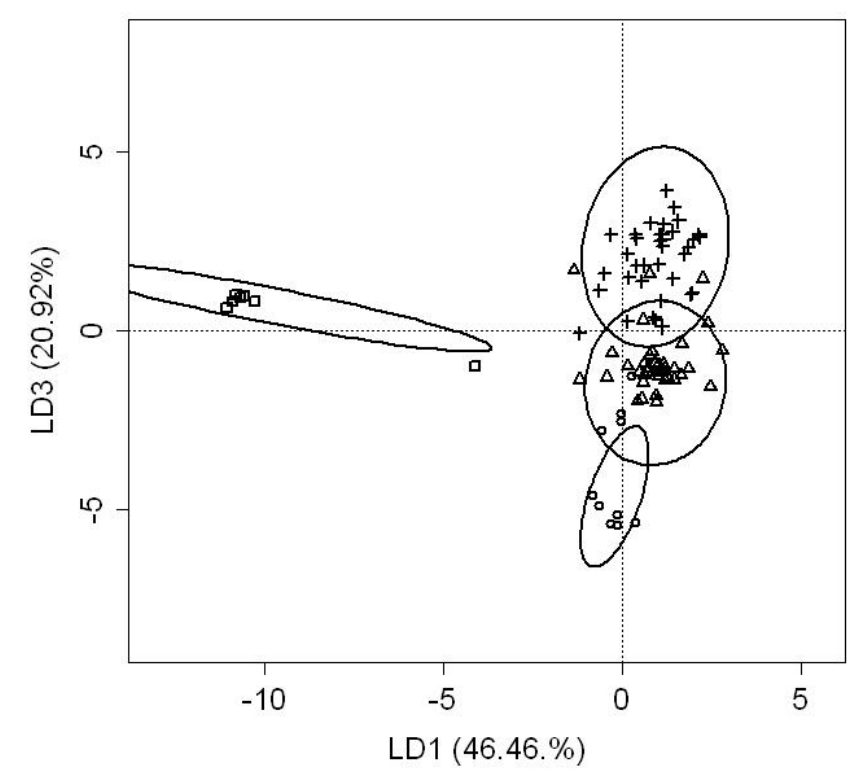

Figure 2. Discrimination of organic and conventional fields in spring and in summer by weed structure according to LD1 and LD3 ( $\square$ conventional in spring, $~$ conventional in summer, $\triangle$ organic in spring, + organic in summer)

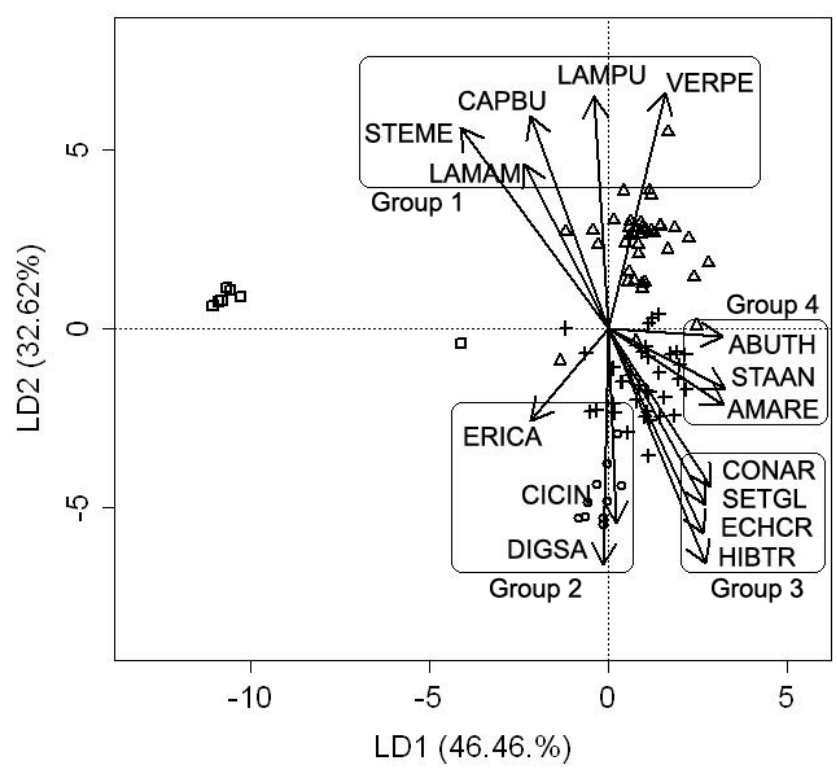

Figure 3. Discriminating species and they effect on the model according to LD1 and LD2 ( $\square$ conventional in spring, $~ O$ conventional in summer, $\triangle$ organic in spring, + organic in summer, ABUTH Abutilon theophrasti, AMARE Amaranthus retroflexus, CAPBU Capsella bursa-pastoris, CICIN Cichorium intybus, CONAR Convolvulus arvensis, DIGSA Digitaria sanguinalis, ECHCR Echinochloa crus-galli, ERICA Conyza canadensis, HIBTR Hibiscus trionum, LAMAM Lamium amplexicaule, LAMPU Lamium purpureum, SETGL Setaria pumila, STAAN Stachys annua, STEME Stellaria media, VERPE Veronica persica.) 
The weeds in group 2 (Cichorium intybus, Conyza canadensis, and Digitaria sanguinalis) described conventional fields in summer, while those of group 4 (Abutilon theophrasti, Amaranthus retroflexus, and Stachys annua) described organic fields in summer. The members of groups 2 and 3, except for Cichorium intybus, are summer annuals that appear in early summer and flower continuously until late summer. These are common in maize fields (Novák et al., 2009; Tóth et al., 2011a, 2011b; Penksza et al., 2010).

The species of weed group 3 are typical of both farming systems in the summer. One of these (Convolvulus arvensis) is a perennial, while the other species (Echinochloa crus-galli, Hibiscus trionum, and Setaria pumila) are summer annuals whose incidence is nonetheless common in the same period. These species are also characteristic of Hungarian arable lands during summer (Novák et al., 2009).

No important species characterized conventional fields in spring, as the weed cover and the number of weed species were low in these fields, and frequently weeds also varied between fields. On the other hand, Convolvulus arvensis (the most frequent weed in these fields) continued to increase in frequency until summer. Cirsium arvense (the second most frequent weed) was common in both farming systems and in both seasons, and so was not able to characterize the 'conventional in spring' group.

The structure coefficients show slight differences, according to LD1 with LD3 and LD1 with LD2 (Fig. 4).

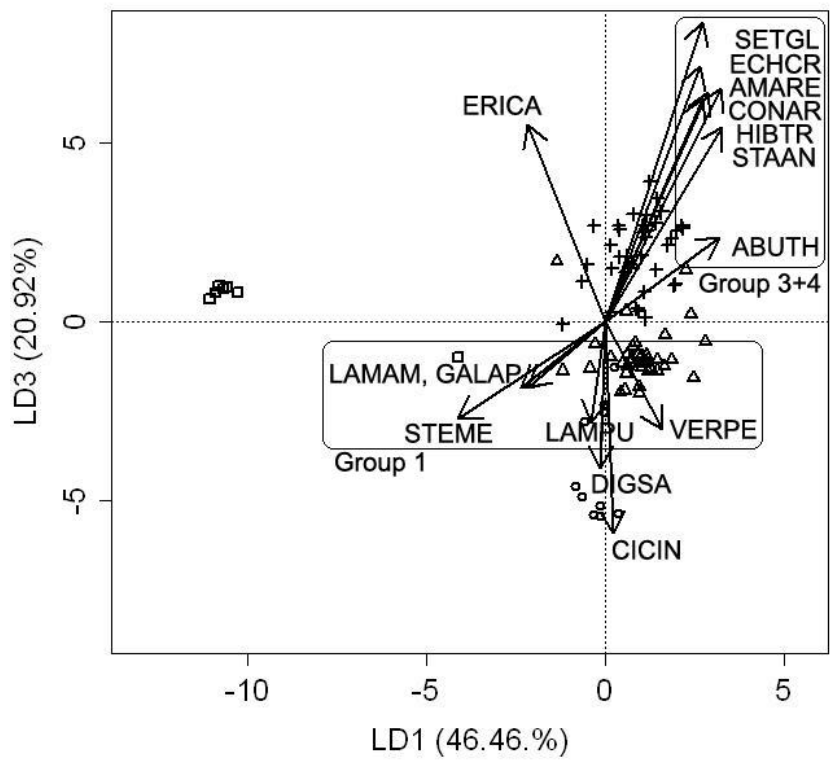

Figure 4. Discriminating species and they effect on the model according to LD1 and LD3 ( $\square$ conventional in spring, $~ O$ conventional in summer, $\triangle$ organic in spring, + organic in summer, ABUTH Abutilon theophrasti, AMARE Amaranthus retroflexus, CAPBU Capsella bursa-pastoris, CICIN Cichorium intybus, CONAR Convolvulus arvensis, DIGSA Digitaria sanguinalis, ECHCR Echinochloa crus-galli, ERICA Conyza canadensis, HIBTR Hibiscus trionum, LAMAM Lamium amplexicaule, LAMPU Lamium purpureum, SETGL Setaria pumila, STAAN Stachys annua, STEME Stellaria media, VERPE Veronica persica.)

The species of groups 3 and 4 are not distinguished, and describe only the organic fields in summer, not the conventional fields in summer. 
From group 2, Cichorium intybus and Digitaria sanguinalis describe conventional fields well in summer, while Conyza canadensis is among the worst descriptors.

The species of group 1 are mainly characteristic of organic fields in spring. The analysis using LD1 with LD2 was more effective than the analysis using LD1 and LD3 in characterizing both group 1 and the two species Digitaria sanguinalis and Cichorium intybus taken together. It was also superior in segregating organic fields in spring from conventional fields in summer.

\section{Conclusions and suggestions}

The evidence of the surveys conducted between 2007 and 2011 is that the organic and conventional areas differ according to many parameters.

The weed species of the summer annual and creeping perennial types are present to a greatest extend in both organic and conventional maize fields, during both survey periods. The cover of species of both types decrease during the growing period of maize. The size of the increase is greater in the case of the summer annuals than with the perennials.

Among summer annual monocotyledons, Echinochloa crus-galli and the Setaria species were common. Other monocot annuals were present only rarely. Organic and conventional fields differed completely in terms of dicotyledonous weeds. Amaranthus retroflexus and Hibiscus trionum had high cover on organic fields in all years. The presence of volunteer Helianthus annuus was common only in conventional fields because of the differences between crop rotations. In addition, the Chenopodium and Persicaria species, as well as Abutilon theophrasti, were frequent in both farming systems. The most common perennials were Cirsium arvense and Convolvulus arvensis, which were found in both farming systems.

Interestingly, the allergenic Ambrosia artemisiifolia was not prominent in either organic or conventional maize fields, although it is common generally in maize fields in Hungary (Novák et al., 2009).

The total weed coverage was higher on organic fields than on conventionals in both periods, and this total coverage could increase during the growing season in both farming systems.

Apart from weed coverage, the structure of the weeds also differed in the two farming systems. Organic fields are characterized by Abutilon theophrasti, Amaranthus retroflexus, and Stachys annua; conventional fields by Digitaria sanguinalis and Cichorium intybus in summer. On organic fields, winter annual species (such as Galium aparine, Lamium spp, Stellaria media, and Veronica persica) were frequent in spring. Conventional spring fields are not characterized by any species, because the weeds that were frequent in such fields were also important in the other field groups.

Acknowledgements. This research was supported by Research Centre of Excellence project (175864/2013/TUDPOL).

\section{REFERENCES}

[1] Bond, W., Grundy, A. C. (2001): Non-chemical weed management in organic farming systems. - Weed Research. 41: 383-405. 
[2] Bonet, A., Pausas, J. G. (2004): Species richness and cover along a 60-year chronosequence in old-fields of south-eastern Spain. - Plant Ecology 174: 257-270.

[3] Bornkamm, R. (1985) Vegetation changes in herbaceous communities. - Handbook of Vegetation Science 3: 89-109.

[4] Brainard, D. C., Bellinder, R. R., Hahn, R. R., Shah, D. A. (2008): Crop rotation, cover crop, and weed management effects on weed seedbanks and yields in snap bean, sweet corn and cabbage. - Weed Science 56: 434-441.

[5] Chamberlain, D. E., Wilson, J. D., Fuller, R. J. (1999) A comparison of bird populations on organic and conventional farm systems in southern Britain. - Biological Conservation 88: 307-320.

[6] DEVELOPMENT CORE TEAM (2011): R: A language and environment for statistical computing. R Foundation for Statistical Computing, Vienna, Austria. ISBN 3-900051-070, URL http://www.R-project.org/.

[7] Dobbs, T. L., Smolik, J. D. (1996) Productivity and Profitability of Conventional and Alternative Farming Systems: A Long-Term On-Farm Paired Comparison. - Journal of Sustainable Agriculture 9: 63-79.

[8] EC 834/2007: Council Regulation on organic production and labelling of organic products and repealing Regulation (EEC) No 2092/91

[9] Edwards, A. R., Mortimer, S. R., Lawson, C. S., Westbury, D. B., Harris, S. J., Woodcock, B. A., Brown, V. K. (2007): Hay strewing, brush harvesting of seed and soil disturbance as tools for the enhancement of botanical diversity in grasslands. - Biological Conservation 134: 372-382.

[10] Gabriel, D., Roschewitz, I., Tscharntke, T., Thies, C. (2006): Beta diversity at different spatial scales: Plant communities in organic and conventional agriculture. - Ecological Applications 16: 2011-2021.

[11] Hakansson, S. (2003): Weeds and Weed Management on Arable Land. An Ecological Approach. Hakasson, S. (ed.): CABI Publishing, Oxon, UK.

[12] Hüppe, J., Hofmeister, H. (1990): Syntaxonomische Fassung und Übersicht über die Ackerunkrautgesellschaften der Bundesrepublik Deutschland. - Berichte der ReinholdTüxen-Gesellschaft 2: 61-81.

[13] Kolbe, H., Meineke, S., Zhang, W. L. (1995): Differences in organic and mineral fertilization on potato tuber yield and chemical composition compared to model calculations. - Agribiology Research. 48: 63- 73.

[14] Kovács, D. (2012): A Hungária Öko Garancia Kft. (HÖG) publikus eves jelentése a 2011. évi ellenőrzési és tanusítási tevékenységéről. Annual Report of the controlling and certification activities of Hungária-Öko-Garancia Ltd in 2011. Hungária Öko Garancia Ltd, Budapest, Hungary.

[15] Krzanowski, W. J. (1988): Principles of Multivariate Analysis. A User's Perspective. Oxford University Press, USA.

[16] Mäder, P., Fliessbach, A., Dubois, D., Gunst, L., Fried, P., Niggli, U. (2002): Soil fertility and biodiversity in organic farming. - Science 296: 1694-1697.

[17] Martins, C. (2009): Farm structure survey in Hungary - 2007. Martins, C. (ed.). Eurostat, Luxembourg.

[18] Németh, I., Sárfalvi, B. (1998): Comparative studies on methodology of weed survey. Növényvédelem 34: 15-22.

[19] Novák, R., Dancza, I., Szentey, L., Karamán, J. (2009) Arable weeds of Hungary. Fifth National Weed Survey 2007-2008. Ministry of Agriculture and Rural Development, Budapest..

[20] Penksza K., Németh I., Dancza I., Tóth A., Bologh Á., Juhász M., Tímár Á., Házi J. (2010): Weed recognition in practice. Syngenta Kft., Budapest.

[21] Pimentel, D., Wilson, C., Mccullum, C., Huang, R., Dwen, P., Flack, J., Tran, Q., Saltman, T., Cliff, B. (1997): Economic and environmental benefits of biodiversity. BioScience 47: 747-757.

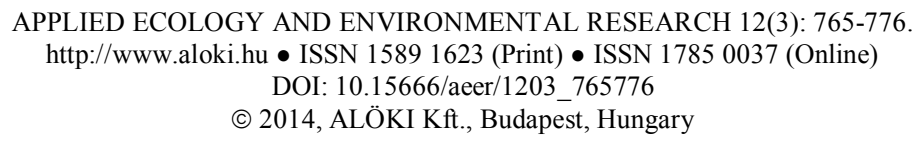


[22] Reganold, J. P., Glover, J. D., Andrews, P. K., Hinman, H. R. (2001) Sustainability of three apple production systems. - Nature 410: 926-930.

[23] Ripley, B.D. (1996): Pattern Recognition and Neural Networks. Cambridge University Press, UK.

[24] Roszik, P., Bálintné-Varga, K., Bánfi, B., Bauer, L., Császár, A., Széles, V., Tőkés, T. (2012): Jelentés a Biokontroll Hungária Kft. 2011. évi tevékenységéről. Annual Report of the activities of Biokontroll Hungária Ltd in 2011. Biokontroll Hungária Ltd, Budapest, Hungary.

[25] Szentes Sz., Sutyinszki Zs., Szabó G., Zimmermann Z., Házi J., Wichmann B., Hufnágel L., Penksza K., Bartha S. (2012): Grazed Pannonian grassland beta-diversity changes due to $\mathrm{C}_{4}$ yellow bluestem. - Cent. Eur. J. Biol. 7(6): 1055- 1065.

[26] Tatoni, T., Roche, P. (1994): Comparison of old-field and forest revegetation dynamics in Provence. - Journal of Vegetation Science 5: 295-302.

[27] Tóth, A., Balogh, Á., Wichmann, B., Berke, J., Gyulai, F., Penksza, P., Dancza, I., Kenéz, Á., Schellenberger, J., Penksza, K. (2011a): Gyomvizsgálatok Pest megyei homoki mezőgazdasági területeken (lucernaföldek gyomvizsgálatai) I. Tájökológiai Lapok 9(2): 449-462.

[28] Tóth, A., Balogh Á., Wichman B., Dancza I., Szalkay Cs., Penksza K. (2011b): Seasonal changes in weed vegetation on arable Pannonian sand and loses lands in Hungary. Hungarian Journal of Industrial Chemistry 39: 313-315.

[29] Venables, W. N., Ripley, B. D. (2002): Modern Applied Statistics with S. Fourth edition. Springer.

[30] Weibel, F. P., Bickel, R., Leuthold, S., Alfoeldi, T. (2000): Are organically grown apples tastier and healthier? A comparative field study using conventional and alternative methods to measure fruit quality. In: Proceedings 1998 XXV International Horticultural Congress, Part 7: Quality of Horticultural Products (Ed M Herregods) (2-7. August, Brussels, Belgium). 417-426. ISHS, Leuven, Belgium.

[31] Zalai, M., Dorner, Z., Kolozsvári, L., Keresztes, Z., Szalai, M. (2012): What does the precision of weed sampling of maize fields depend on? - Növényvédelem 48: 451-456. 